Section Editor

Mitchell S.V. Elkind,

MD, MS

Pearls \& Oy-sters:

\title{
Chronic mumps meningoencephalitis with low CSF glucose and acute hydrocephalus in an adult
}

Ines Escalza-Cortina, MD

Itxaso Azkune-Calle, MD

Aida Rodriguez-Sainz,

$\mathrm{MD}$

Marian Gomez-

Beldarrain, MD

Iñigo Vicente-Olabarría, MD

Juan Carlos Garcia-

Monco, MD

Correspondence to

Dr. Garcia-Monco:

hospit05@sarenet.es

\section{PEARLS}

- Chronic lymphocytic meningoencephalitis with low glucose and increased adenosine deaminase (ADA) levels in the CSF together with hydrocephalus represents a diagnostic challenge of varied etiology and only seldom is due to a viral (mumps) infection.

- Mumps meningoencephalitis may occur in the absence of orchitis or parotitis.

\section{OY-STERS}

- This infrequent association, described in children and exceptional in adults, requires mumps serology and PCR in the CSF to establish the etiology and to avoid empiric treatment of other chronic infections (i.e., tuberculosis) or inflammatory disorders (i.e., sarcoidosis) that may result in the same association.

- Neurologic complications of mumps infection might occasionally occur in vaccinated individuals, since vaccination does not confer full protection.

CASE REPORT A 55-year-old woman was admitted to the emergency department for a 24-hour episode of malaise followed by progressive somnolence and fever of $39^{\circ} \mathrm{C}$. A cranial CT scan showed moderate hydrocephalus. She became agitated and developed a generalized seizure. Examination was normal, and neurologic examination revealed an obtunded patient with no meningeal signs or focal findings.

A ventriculoperitoneal catheter had been placed 25 years before for a Chiari type I malformation with hydrocephalus. The patient developed a gastrocolic fistula and the device was removed. She remained well and hydrocephalus resolved.

In 2008, the patient had undergone a lumbar puncture for acute headache, and the CSF parameters were all normal (glucose $82 \mathrm{mg} / \mathrm{dL}$, ADA $3 \mathrm{U} / \mathrm{L}$ [normal $<5 \mathrm{U} / \mathrm{L}$ ], proteins $45 \mathrm{mg} / \mathrm{dL}, 2$ cells $\mathrm{mm}^{3}$ ). She had not been vaccinated for mumps.

A lumbar puncture was performed in the emergency department, and the CSF showed a lymphocytic pleocytosis with increased proteins and ADA levels, and low glucose. The table shows the evolution of different values over time.

The complete blood count and differential were normal, as was C-reactive protein and erythrocyte sedimentation rate, and blood chemistry indicated mild cholestasis. HIV serology was negative. A chest $\mathrm{x}$-ray was normal and a tuberculin skin test was negative. An EEG showed diffuse slowing without paroxysmal features. A brain MRI showed evidence of acute hydrocephalus with cerebrospinal transudate and intraventricular synechiae, as well as an area of gliosis secondary to catheter placement on the right parietal lobe (figure).

While waiting for the cultures, antituberculous therapy was empirically started on day 3 after admission. Mycobacterial, fungal, and conventional CSF cultures were negative on 4 different samples.

Two weeks after admission, the patient's family reported that 3 close relatives had been diagnosed with mumps. Although parotid enlargement was not noted, serum and CSF antibodies for mumps virus were positive (immunoglobulin $\mathrm{M}[\mathrm{IgM}]$ and immunoglobulin G [IgG]), consistent with an acute infection. Specific IgG quantification against the mumps virus showed a serum titer of 55,000 (normal 0-32) and a CSF titer of 22,000 (normal 0-32). Intrathecal synthesis of $\mathrm{IgG}$ against mumps (index of $\mathrm{IgG}$ against mumps in CSF/ albumin index) was greatly increased at 34.4. PCR for mumps virus in the CSF was positive (genotype G1) on a sample obtained on day 10 after admission but was negative on a sample obtained on day 18 after admission. Oligoclonal bands were present in the CSF of a sample obtained on day 10 after admission. IgM oligoclonal bands were present with a type IV pattern (bands in serum mirror those in CSF; this pattern is consistent with systemic IgG synthesis) and IgG with a type III pattern (identical bands in both serum and CSF with extra bands in CSF, which demonstrates both intrathecal and systemic IgG synthesis).

PCR for herpes simplex virus, varicella-zoster virus, enterovirus, and Tropheryma whipplei in the CSF was negative, and tuberculous therapy was withheld.

From the Service of Neurology (I.E.-C., I.A.-C., A.R.-S., M.G.-B., J.C.G.-M.) and OSATEK-Magnetic Resonance Imaging Unit (I.V.-O.), Hospital de Galdakao-Usansolo, Galdakao, Vizcaya, Spain.

Go to Neurology.org for full disclosures. Funding information and disclosures deemed relevant by the authors, if any, are provided at the end of the article. 


\begin{tabular}{|c|c|c|c|c|c|c|c|}
\hline Evolution of CSF values & & & & & & & \\
\hline & Admission & Day 10 & Day 14 & Day 24 & Day 31 & Day 36 & Month 4 \\
\hline Glucose $(\mathrm{mg} / \mathrm{dL}$, normal $>45)$ & 41 (serum glucose, 89 mg/dL) & 37 & 40 & 37 & 37 & 59 & 57 \\
\hline Proteins (mg/dL, normal < 45) & 238 & 508 & 207 & 147 & 123 & 105 & 71 \\
\hline Leukocytes (lymphocyte percentage) & 456 (99) & 804 (95) & $94(96)$ & 35 (98) & 20 (99) & $53(100)$ & $9(90)$ \\
\hline Adenosine deaminase $(\mathrm{U} / \mathrm{L}$, normal $<5)$ & 13.9 & 37.7 & 22.8 & 15.5 & 9.8 & 8.3 & 5 \\
\hline IgG index (normal, <0.7) & ND & 1.72 & 2.14 & 2.06 & 1.81 & 2.79 & 1.47 \\
\hline PCR for mumps & ND & Positive (genotype G1) & Negative & ND & ND & ND & ND \\
\hline
\end{tabular}

Abbreviations: IgG = immunoglobulin G; ND = not done.

Repeated brain MRI showed progressive hydrocephalus improvement (figure).

The patient was discharged and showed a favorable evolution over the following 3 months, with progressive improvement of the CSF without treatment. The last CSF sample, 4 months after the initial symptoms, contained 9 cells $/ \mathrm{mm}^{3}$ and normal protein and glucose contents.

DISCUSSION We report a patient with a chronic (>4 weeks) lymphocytic meningoencephalitis with decreased glucose, increased ADA levels, and hydrocephalus that initially led to a suspicion of tuberculous meningitis. The final diagnosis was based on mumps PCR and serology in the CSF with evidence of intrathecal synthesis of specific antibodies to the mumps virus, the ruling out of other etiologies, the presence of

\section{Figure Brain MRI shows hydrocephalus and ventricular synechiae at the sylvian aqueduct and foramen of Magendie}

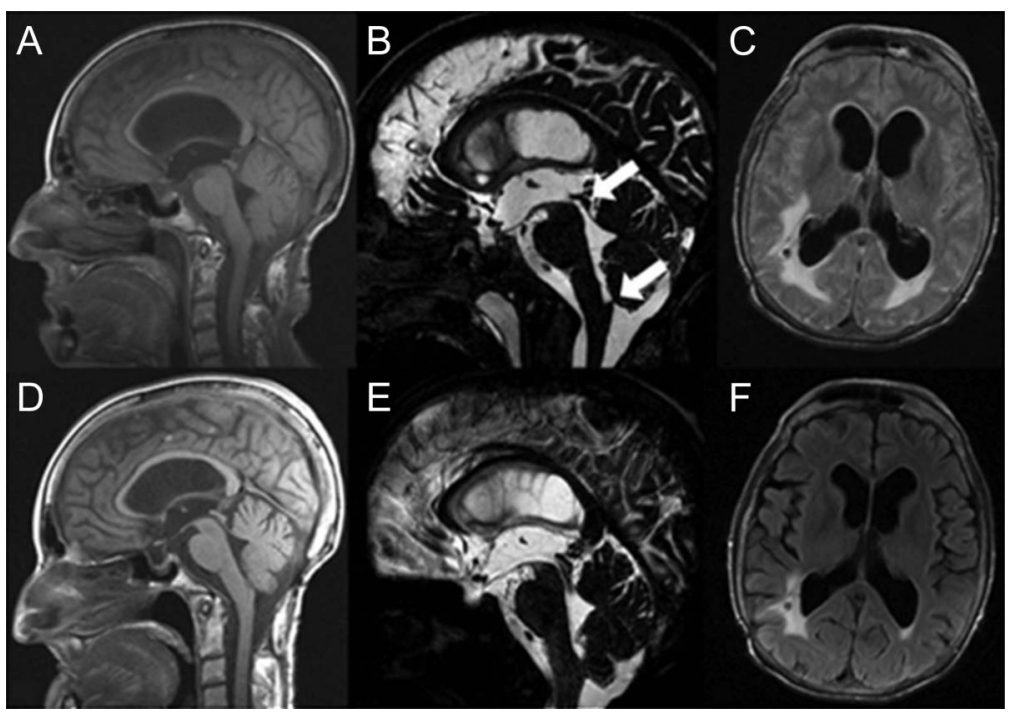

Brain MRI on admission shows acute obstructive hydrocephalus (A) with ventricular synechiae at the sylvian aqueduct and formen of Magendie (3D constructive interference in steadystate sequence). There was absence of CSF void flow signal in the ventricular system (C). The abnormal periventricular white matter signal $(B$, fluid-attenuated inversion recovery sequence) suggests transependymal CSF migration. A brain MRI 3 weeks later showed hydrocephalus improvement and lesser white matter signal abnormality (D, F). Synechiae had resolved and there was CSF flow void signal (E). mumps cases in her family, and a favorable evolution without specific therapy. PCR was positive in the CSF on day 10 after admission and was negative 1 week later. The timing of PCR is important in viral infection since it may result in false-negatives, particularly if obtained too early or too late in the disease.

Mumps is an acute generalized viral infection that occurs primarily in children and adolescents. The most prominent clinical manifestation is unilateral or bilateral parotid swelling. ${ }^{1}$ Recently, concern has been raised about vaccine failure and infection resurgence, with important outbreaks in the United Kingdom in 2005 and in the United States in 2006. ${ }^{1,2}$ Prior to widespread vaccination, mumps was a main cause of aseptic meningitis. The vaccine with live attenuated virus is protective but imperfect, and outbreaks still occur even among vaccinated individuals. This patient had not been vaccinated. Twelve different genotypes (A to L) with subgenotypes of mumps virus have been described, all belonging to the same serotype; despite being the same serotype, lack of full cross-protection between different genotypes has been reported. It has been suggested that different genotypes may differ in their ability to invade the nervous system and cause disease, although this is not universally accepted. In Spain, G1 genotype is dominant after 2003, when it replaced genotype $\mathrm{H} 1$, and was responsible for outbreaks between 2006 and 2009. ${ }^{3}$

Although it is usually a self-limited and benign disorder, mumps occasionally complicates with extrasalivary manifestations (orchitis and CNS involvement), particularly in older patients. ${ }^{4}$ Meningitis occurs in $10 \%$ of patients and encephalitis in up to $0.1 \% .^{1}$ Meningitis may occur without parotid involvement in half of the cases. Hydrocephalus has been reported in children but is exceptional in adults, ${ }^{5,6}$ and has been attributed to granular ependymitis due to mumps infection of the ependymal cells followed by occlusion of the aqueduct. In contrast to the acute hydrocephalus of our patient, most reported cases appeared late in the course of the infection. The fact that this patient had a Chiari type I malformation in the past could have facilitated the development of ventriculomegaly. 
Prolonged CSF pleocytosis (up to 5 weeks) with decreased glucose has been reported, but always in children. ${ }^{7}$ Our patient still had a slight CSF pleocytosis 4 months after disease onset. However, it may be argued that due to the usually benign course of the disease, most patients do not undergo serial lumbar punctures to verify the timing of CSF normalization, and that CSF abnormalities may persist (undetected) for longer periods of time. Low CSF glucose levels usually indicate bacterial or neoplastic meningitis, but up to $25 \%$ of mumps meningitis patients have hypoglychorrachia. The mechanism of hypoglychorrachia in mumps meningitis is unclear. An alteration in the glucose transport system into the CSF has been proposed as a potential explanation $^{8}$ and seems more plausible than glucose consumption by the virus.

This system explains the delay ( 2 hours) in equilibration of the CSF glucose after a rapid change in serum glucose concentrations (i.e., after IV administration of glucose or hypoglycemia). For these reasons, some authors prefer to use the CSF concentration of glucose (abnormal below $45 \mathrm{mg} / \mathrm{dL}$ ) rather than the blood to CSF ratio. The entry of glucose into the CSF is altered in tuberculous meningitis and likely in other lymphocytic meningitis, including some viral infections as well.

Although infrequent, mumps should be included in the differential diagnosis of chronic lymphocytic meningoencephalitis in the adult, even in the presence of low CSF glucose and high ADA levels in the CSF and neuroimaging evidence of hydrocephalus. The differential diagnosis with tuberculosis is particularly challenging?; one case of coinfection has been reported. ${ }^{10}$

\section{AUTHOR CONTRIBUTIONS}

Drs. Escalza-Cortina, Azkune-Calle, Rodriguez-Sainz, Gomez-Beldarrain, and Garcia-Monco were involved in the clinical care of this patient and participated in writing the manuscript. Dr. Vicente-Olabarria performed the MRI studies. The final version was read and approved by all the authors.

\section{STUDY FUNDING}

No targeted funding reported.

\section{DISCLOSURE}

The authors report no disclosures relevant to the manuscript. Go to Neurology.org for full disclosures.

\section{REFERENCES}

1. Hviid A, Rubin S, Muhlemann K. Mumps. Lancet 2008; 371:932-944.

2. Gershamn K; Centers for Disease Control. Update: multistate outbreak of mumps: United States, January 1-May 2, 2006. MMWR Morb Mortal Wkly Rep 2006;55:559-563.

3. Royuela E, Castellanos A, Sanchez-Herrero C, Sanz JC, De Ory F, Echevarria JE. Mumps virus diagnosis and genotyping using a novel single RT-PCR. J Clin Virol 2011;52:359-362.

4. Levitt LP, Rich TA, Kinde SW, Lewis AL, Gates EH, Bond JO. Central nervous system mumps: a review of 64 cases. Neurology 1970;20:829-834.

5. Timmons GD, Johnson KP. Aqueductal stenosis and hydrocephalus after mumps encephalitis. N Engl J Med 1970;283:1505-1507.

6. Cinalli G, Spennato P, Ruggiero C, Aliberti F, Maggi G. Aqueductal stenosis 9 years after mumps meningoencephalitis: treatment by endoscopic third ventriculostomy. Childs Nerv Syst 2004;20:61-64.

7. Wilfert CM. Mumps meningoencephalitis with low cerebrospinal-fluid glucose, prolonged pleocytosis and elevation of protein. N Engl J Med 1969;280:855-859.

8. Wilfert CM. Low CSF sugar in mumps. N Engl J Med 1969;281:106.

9. Jongeling AC, Pisapia D. Pearls \& Oy-sters: tuberculous meningitis: not a diagnosis of exclusion. Neurology 2013; 80:e36-e39.

10. Kalis NN, Donald PR, Burger PJ, Becker WB. Simultaneous occurrence of mumps meningoencephalitis and tuberculosis meningitis. Pediatr Infect Dis J 1989;8: 476-477. 


\section{Neurology}

\section{Pearls \& Oy-sters: Chronic mumps meningoencephalitis with low CSF glucose and acute hydrocephalus in an adult}

Ines Escalza-Cortina, Itxaso Azkune-Calle, Aida Rodriguez-Sainz, et al.

Neurology 2014;82;e41-e43

DOI 10.1212/WNL.0000000000000081

This information is current as of February 3, 2014

\section{Updated Information \&} Services

References

Subspecialty Collections

Permissions \& Licensing

Reprints including high resolution figures, can be found at: http://n.neurology.org/content/82/5/e41.full

This article cites 10 articles, 2 of which you can access for free at: http://n.neurology.org/content/82/5/e41.full\#ref-list-1

This article, along with others on similar topics, appears in the following collection(s):

All Clinical Neurology

http://n.neurology.org/cgi/collection/all_clinical_neurology All Infections

http://n.neurology.org/cgi/collection/all_infections

Meningitis

http://n.neurology.org/cgi/collection/meningitis

Viral infections

http://n.neurology.org/cgi/collection/viral_infections

Information about reproducing this article in parts (figures,tables) or in its entirety can be found online at:

http://www.neurology.org/about/about_the_journal\#permissions

Information about ordering reprints can be found online:

http://n.neurology.org/subscribers/advertise

Neurology ${ }^{\circledR}$ is the official journal of the American Academy of Neurology. Published continuously since 1951 , it is now a weekly with 48 issues per year. Copyright @ 2014 American Academy of Neurology. All rights reserved. Print ISSN: 0028-3878. Online ISSN: 1526-632X.

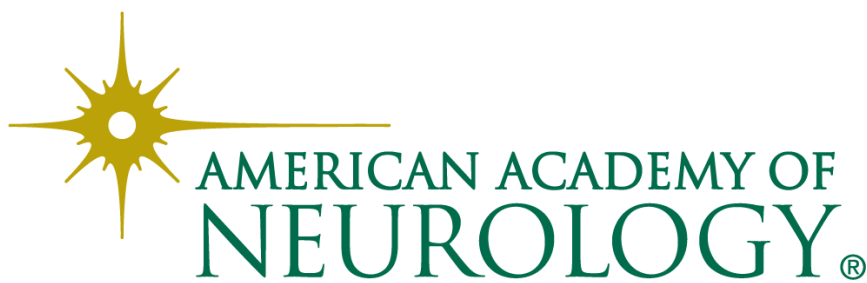

